\title{
THE
}

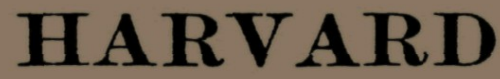

\section{THEOLOGICAL REVIEW}

Issued quarterly by the Faculty of Divinity in

Harvard University, Cambridge, Massachusetts.

\section{Editorial Committee}

Grorae F. Moorm

JAMES H. ROPES
WIILIAM W. FENN

Freederic Palmer

The Harvard Theological Review is an undenominational theological quarterly, established by the aid of the bequest of Miss Mildred Everett, daughter of Feverend Charles Carroll Everett, D.D., Bussey Professor of Theology in the Harvard Divinity School, 1869-1900, and Dean of the School, 1878-1900.

The Review aims to include discussions in the various fields of theological study and also in the history of religions, ethics, education, economics, and sociology, in their theological and religious aspects. It is designed to serve the needs not only of clergymen and scholars, but of all who are interested in religious thought and in the place and function of religion in modern life.

Remittances and communications on business matters should be addressed to the Director of the Harvard University Press, Cambridge, Massachusetts.

\section{PUBLISHED BY THE \\ HARVARD UNIVERSITY PRESS \\ Cambridge}

Entered as second-class mail matter January 2. 1908, at the post-office at Boston, Mass., under the act of Congress of March 3,1879 